\title{
Association between lymphocyte count in bronchoalveolar lavage fluid and mortality
}

Yifu Si ${ }^{1}$, Juqin Shao ${ }^{2}$ and Caibao $\mathrm{Hu}^{2 *}$

\begin{abstract}
This is a comment on the paper by Dr. Hirasawa et al. on the predictive value of lymphocyte counts in bronchoalveolar lavage fluid in patients with acute respiratory failure.
\end{abstract}

Keywords: Acute respiratory failure, Bronchoalveolar lavage fluid, Interstitial lung disease, Lymphocyte

\section{To the Editor,}

We read with great interest Dr. Hirasawa et al's study [1], which investigated the predictive value of lymphocyte counts in bronchoalveolar lavage fluid (BALF) in patients with acute respiratory failure (ARF). This study is well designed. However, several issues should be noted when interpreted these findings.

First, ARF is a heterogeneous syndrome with various etiologies. The predictive ability of lymphocytes in BALF may be different in different diseases. For instance, in the current study, almost half of the included patients (38/78) had a diagnosis of interstitial lung disease (ILD). According to the American Thoracic Society clinical practice guideline [2], lymphocytic cellular pattern (lymphocyte count $>15 \%$ in BALF) is common in ILD. Whether the cutoff value of lymphocytes is different from other diseases remains unclear. In addition, studies are reporting that the lymphocyte in BALF did not show significant predictive value in different diseases. In a study of corona virus disease 2019 [3], Takei et al. reported that patients with high or low BALF lymphocyte ( $>25$ vs. $<25 \%$ ) had comparable disease severity either on intensive care unit admission or on the day of BALF extraction. In a study

*Correspondence: hucaibaozhejiang@163.com

${ }^{2}$ Department of Intensive Care, Zhejiang Hospital, 1220\#,

Gudun-RoadZhejiang, Hangzhou 310030, China

This article refers to the article available online at https://doi.org/10.1186/

s40560-021-00572-6.

Full list of author information is available at the end of the article of non-cystic fibrosis bronchiectasis [4], the lymphocyte count in BALF was comparable between the infection and non-infection groups. The stability of these findings $[3,4]$ may be uncertain due to the relatively small sample size. However, whether the current findings applied to ARF patients caused by different diseases also need to be investigated in future studies.

In addition, in the current study, ILD is associated with decreased mortality. This is a little unexpected. In another multicenter observational study including four different cohorts [5] $(n=2633,5320,2068$, and 1670, respectively), interstitial lung abnormalities were consistently associated with a higher risk of all-cause mortality. There is a possibility that this difference was caused by the small sample size. However, if this is the case, the current finding would be biased. For instance, if the presence of ILD was associated with increased mortality in a real world, there should be more ILD patients in the non-survivor group in the current study, which may be missed due to sampling error. In this case, the association between lymphocyte and mortality might be biased.

\section{Abbreviations}

ARF: Acute respiratory failure; BALF: Bronchoalveolar lavage fluid; ILD: Interstitial lung disease.

\section{Acknowledgements}

None. original author(s) and the source, provide a link to the Creative Commons licence, and indicate if changes were made. The images or other third party material in this article are included in the article's Creative Commons licence, unless indicated otherwise in a credit line to the material. If material is not included in the article's Creative Commons licence and your intended use is not permitted by statutory regulation or exceeds the permitted use, you will need to obtain permission directly from the copyright holder. To view a copy of this licence, visit http://creativecommons.org/licenses/by/4.0/. The Creative Commons Public Domain Dedication waiver (http://creativeco mmons.org/publicdomain/zero/1.0/) applies to the data made available in this article, unless otherwise stated in a credit line to the data. 


\section{Authors' contributions}

$\mathrm{CH}$ raised the question; JS wrote the whole manuscript; YS made final revision.

All authors read and approved the final manuscript.

\section{Funding}

None.

\section{Availability of data and materials}

Not applicable.

\section{Declarations}

Ethics approval and consent to participate

Not applicable.

\section{Consent for publication}

Not applicable.

\section{Competing interests}

Not applicable.

\section{Author details}

'Department of Internal Medicine, Pinghu First People's Hospital, 500\#, Sangang-Road, Pinghu, Zhejiang, China. ${ }^{2}$ Department of Intensive Care, Zhejiang Hospital, 1220\#, Gudun-RoadZhejiang, Hangzhou 310030, China.
Received: 16 July 2021 Accepted: 13 August 2021

Published online: 15 September 2021

\section{References}

1. Hirasawa Y, Nakada TA, Shimazui T, et al. Prognostic value of lymphocyte counts in bronchoalveolar lavage fluid in patients with acute respiratory failure: a retrospective cohort study. J Intensive Care. 2021;9(1):21.

2. Meyer KC, Raghu G, Baughman RP, et al. An official American Thoracic Society clinical practice guideline: the clinical utility of bronchoalveolar lavage cellular analysis in interstitial lung disease. Am J Respir Crit Care Med. 2012:185(9):1004-14.

3. Voiriot G, Fajac A, Gibelin A, Parrot A, Fartoukh M. Alveolar lymphocytosis with plasmacytosis in severe COVID-19. Respir Med Res. 2020;78: 100784

4. Kapur N, Grimwood K, Masters IB, Morris PS, Chang AB. Lower airway microbiology and cellularity in children with newly diagnosed non-CF bronchiectasis. Pediatr Pulmonol. 2012;47(3):300-7.

5. Putman RK, Hatabu H, Araki T, et al. Association between interstitial lung abnormalities and all-cause mortality. JAMA. 2016;315(7):672-81.

\section{Publisher's Note}

Springer Nature remains neutral with regard to jurisdictional claims in published maps and institutional affiliations.
Ready to submit your research? Choose BMC and benefit from:

- fast, convenient online submission

- thorough peer review by experienced researchers in your field

- rapid publication on acceptance

- support for research data, including large and complex data types

- gold Open Access which fosters wider collaboration and increased citations

- maximum visibility for your research: over 100M website views per year

At $\mathrm{BMC}$, research is always in progress.

Learn more biomedcentral.com/submissions 